\title{
David J. Bond, Pierre Michon : autobiographical fiction and the creation of identity
}

\section{Elisa Bricco}

\section{(2) OpenEdition}

1 Journals

\section{Edizione digitale}

URL: https://journals.openedition.org/studifrancesi/41288

DOI: $10.4000 /$ studifrancesi.41288

ISSN: 2421-5856

\section{Editore}

Rosenberg \& Sellier

\section{Edizione cartacea}

Data di pubblicazione: 1 juillet 2004

Paginazione: 225

ISSN: 0039-2944

\section{Notizia bibliografica digitale}

Elisa Bricco, «David J. Bond, Pierre Michon : autobiographical fiction and the creation of identity», Studi Francesi [Online], 142 (XLVIII | I) | 2004, online dal 30 novembre 2015, consultato il 09 septembre 2021. URL: http://journals.openedition.org/studifrancesi/41288; DOI: https://doi.org/10.4000/studifrancesi. 41288

Questo documento è stato generato automaticamente il 9 septembre 2021.

\section{(c) 9 (i) $\Theta$}

Studi Francesi è distribuita con Licenza Creative Commons Attribuzione - Non commerciale - Non opere derivate 4.0 Internazionale. 


\title{
David J. Bond, Pierre Michon : autobiographical fiction and the creation of identity
}

\author{
Elisa Bricco
}

\section{NOTIZIA}

DAVID J. BOND, Pierre Michon : autobiographical fiction and the creation of identity, «L'Esprit Créateur», 2002, XLII, 4, pp.58-65.

1 Il carattere autobiografico dei testi di Michon è ormai stato appurato e lungamente studiato. Situandosi nel contesto degli studi sull'autobiografismo e l'autofiction, l'A. mette in luce una caratteristica particolare dello statuto dello scrittore all'interno delle opere michoniane: la ricerca di sé nella scrittura, nel testo e nella lettura. In effetti, proiettando se stesso nel testo, Michon crea un'immagine di sé, che attraverso la percezione del lettore diventa reale: così l'identità ricercata dello scrittore, che innanzittutto si cerca come tale, viene alla luce per mezzo dell'ultimo anello della catena della ricezione, il lettore. 